DOI: https://doi.org/10.18371/fp.3(39).2020.215186

УДК 338.001.36 : [334.722]

\title{
МІЖНАРОДНІ ІНДЕКСНІ СИСТЕМИ ОЦІНКИ БІЗНЕС-СЕРЕДОВИЩА В УКРАЇНІ
}

\author{
ОНИЩЕНКО Світлана Володимирівна \\ д.е.н., професор кафедри фінансів, \\ банківського бізнесу та оподаткування \\ Національний університет \\ «Полтавська політехніка імені Юрія Кондратюка» \\ ORCID ID: http://orcid.org/0000-0002-6173-4361 \\ e-mail:s07onyshchenko@gmail.com
}

МАСЛІЙ Олександра Анатоліївна

к.е.н., дочент кафедри фінансів,

банківського бізнесу та оподаткування

Національний університет

«Полтавська політехніка імені Юрія Кондратюка»

ORCID ID: http://orcid.org/0000-0003-2184-968X

e-mail:pugachaleksa@gmail.com

\begin{abstract}
Анотація. Дослідження проблем розвитку бізнес-середовища та оцінка його якісних характеристик з огляду на досягнення пріоритетних иілей розвитку бізнесу в Украӥні розглядається як один із головних напрямів відновлення економічного зростання та підвищення добробуту громадян краӥни. Узагальнено показники та методики оцінювання бізнес-середовища з використанням транснаціональних компаративних міжнародних індексних систем. Виявлено критичні відставання України від середньосвітових параметрів конкурентоспроможності начіональної економіки. Зроблено висновок, щзо нагальною є необхідність усунення інституиійних деформачій бізнес-середовищя, максимальної захищеності від опортуністичної поведінки економічних агентів, дуалізму законодавчого забезпечення та в цүілому покрашення vмов ведення бізнесу.
\end{abstract}

Ключові слова: бізнес-середовище, загрози, інституиійні деформації, індексні системи оцінки.
Аннотация. Исследование проблем развития бизнес-среды и оченка его качественных характеристик с учетом достижения приоритетных иелей развития бизнеса в Украине рассматривается как одно из главных направлений восстановления экономического роста и повышения благосостояния граждан страны. Обобщенно показатели и методики оиенки бизнес-среды с использованием транснациональных компаративных международных индексных систем. Обнаружено критические отставание Украины от среднемировых параметров конкурентоспособности начиональной экономики. Сделан вывод, что существует необходимость устранения институциональных деформаций бизнес-среды, максимальной защищенности от оппортунистического поведения экономических агентов, дуализма законодательного обеспечения и в целом улучшение условий ведения бизнеса.

Ключевые слова: бизнес-среда, угрозы, институцииональные деформации, индексные системы оценки. 
Постановка проблеми. В Україні вирішуються надзвичайно складні й відповідальні завдання, пов'язані 3 трансформаційним процесом в національній економіці, який протікає під дією глобальних викликів, історичних чинників та економічних законів, непомірно затягнутий в часі, а в останні роки супроводжується й кризовими явищами та негативними тенденціями розвитку бізнес-середовища. За 29 років в Україні бізнес зазнав численних випробувань й продовжує перебувати в економічній турбулентності. Як зазначають в бізнес-асоціаціях, оцифрувати потенційні збитки у зв'язку з пандемією фактично неможливо через складність прогнозування поте-нційних масштабів поширення вірусу в Україні [1]. Виникає необхідність аналітичного дослідження формування спри-ятливого бізнессередовища та виявлення впливу чинників на бізнес з метою ідентифікації потенційних загроз та можливостей, на основі чого формуються стратегічні напрями розвитку бізнес-середовища на макро- та мікрорівні.

Аналіз останніх досліджень і публікацій. Процеси формування та розвитку бізнес-середовища значною мірою визначаються зовнішніми умовами, в якому функціонує підприємство. Проблеми визначення складових бізнес-середовища, зовнішніх умов ведення бізнесу, конкурентних переваг висвітлені в працях зарубіжних і українських науковців, зокрема Д. Норта, Й. Шумпетера, М. Портера, 3. Варналія [4], М. Козоріз, С. Покропивного та інших. Проблематику формування бізнес-середовища в умовах інституційних трансформацій досліджено в роботах М. Мельник [3], І. Біла, Н. Насікан [4], С. Страшний [5]. Дос- лідження підприємницького сектора економіки та напрямів удосконалення регуляторної політики зробили такі вчені: Т. Васильців, М. Долішній, С. Дрига, Я. Жаліло і ін. Проте недостатньо дослідженими залишаються умови розвитку бізнес-середовища та ведення бізнесу в Україні.

Метою статті $\epsilon$ порівняльний аналіз бізнес-середовища 3 використанням транснаціональних компаративних індексних систем для виявлення сучасних проблем розвитку бізнесу в Україні.

Виклад основних результатів. Сучасна економічна наука дає підстави розглядати бізнес-середовище як складну, багатовимірну, поліфункціональну систему, яка формується суб'єктами економіки та інститутами, а також чинниками правового, політичного, соціального, економічного характеру, які створюють умови функціонування і розвитку бізнесу, здійснення ділових відносин, використання потенціалу, досягнення цілей суб'єктів господарювання $[2 ; 3$; 4, с.127-128]. Сьогодні пріоритети розвитку бізнес-середовища істотною мірою зумовлюють формування міжнародної системи правил нового світового порядку, які в широкому значенні можна розуміти як правила узгодженої взаємодії економічних агентів в умовах глобалізації. Це пов'язано 3 тим, що змінюється інституціональне середовище функціонування бізнесу в світі.

Інституційні механізми розвитку бізнес-середовища насамперед стосуються функцій держави як складного й найважливішого суспільного інституту $[3 ; 7]$. При цьому інституційні умови формуються під впливом розгалуженої системи регулювання та підт- 
римки бізнесу, створюються нормативно-правовим забезпеченням як полем взаємодії суб' єктів бізнесу та держави. Водночас регуляторні умови повинні спрямовуватись на прозорість і послідовність державної політики у сфері регулювання бізнесу, що забезпечується через процеси ліцензування, реєстрації, сертифікації підприємницької діяльності тощо.

Стан бізнес-середовища визначається як інституційним забезпеченням, так і чинниками впливу (стимуляторами і дестимуляторами). Для оцінювання стану бізнес-середовища в тій чи іншій країні використовується транснаціональні індексні системи (табл. 1), які поєднують статистичні показники розвитку національних економік з показниками експертних оцінок, на основі чого формуються інтегральні індекси для оцінки бізнессередовища країни.

Таблиця 1

Міжнародні компаративні індексні системи оцінки бізнес середовища

\begin{tabular}{|c|c|c|c|c|}
\hline $\begin{array}{l}\text { № } \\
3 / \Pi\end{array}$ & $\begin{array}{c}\text { Назва си- } \\
\text { стеми оцін- } \\
\text { ки }\end{array}$ & $\begin{array}{c}\text { Організа- } \\
\text { ція, що } \\
\text { здійснює } \\
\text { оцінюван- } \\
\text { ня }\end{array}$ & $\begin{array}{c}\text { Мета } \\
\text { дослідження }\end{array}$ & $\begin{array}{c}\text { Індикатори, що використовуються, } \\
\text { методика розрахунку }\end{array}$ \\
\hline 1 & 2 & 3 & 4 & 5 \\
\hline 1 & $\begin{array}{l}\text { Індекс } \\
\text { легкості } \\
\text { ведення } \\
\text { бізнесу } \\
\text { (Doing } \\
\text { Business, } \\
\text { DB) }\end{array}$ & $\begin{array}{l}\text { Світовий } \\
\text { Банк (World } \\
\text { Bank) }\end{array}$ & $\begin{array}{l}\text { Порівняння прос- } \\
\text { тоти підприємниць- } \\
\text { кої діяльності між } \\
\text { країнами світу, дос- } \\
\text { лідження впливу } \\
\text { регуляції бізнесу } \\
\text { державою на еконо- } \\
\text { мічне зростання }\end{array}$ & $\begin{array}{l}\text { Загальний індекс базується на десяти } \\
\text { внутрішніх індикаторах: реєстрація } \\
\text { підприємств, отримання дозволів на } \\
\text { будівництво, підключення до електро- } \\
\text { мереж, реєстрація власності, доступ до } \\
\text { кредитів, захист прав інвесторів, опод- } \\
\text { ткування, міжнародна торгівля, забез- } \\
\text { печення виконання контрактів, ліквід- } \\
\text { ція підприємств. Індекс не враховує } \\
\text { загальніші умови, такі як інфра- } \\
\text { структура, інфляція та злочинність. }\end{array}$ \\
\hline 2 & \begin{tabular}{l}
\multicolumn{1}{c}{ Індекс } \\
глобальної \\
конкуренто- \\
спромож- \\
ності (The \\
Global \\
Competitive \\
ness Index, \\
GCI)
\end{tabular} & $\begin{array}{l}\text { Всесвітній } \\
\text { економіч- } \\
\text { ний форум } \\
\text { (World } \\
\text { Economic } \\
\text { Forum) }\end{array}$ & $\begin{array}{l}\text { Вимірювання кон- } \\
\text { курентоспромож- } \\
\text { ності національних } \\
\text { економік як здат- } \\
\text { ності країни забез- } \\
\text { печувати стабільні } \\
\text { темпи економічного } \\
\text { зростання, які були б } \\
\text { стійкі в середньо- } \\
\text { строковій перспек- } \\
\text { тиві }\end{array}$ & $\begin{array}{l}98 \text { індикаторів, які згруповано в } \\
12 \text { узагальнюючих показників - } \\
\text { драйверів продуктивності, які визна- } \\
\text { чають рівень конкурентоспромож- } \\
\text { ності країни. Третина індикаторів - } \\
\text { статистичні дані, решта - експертні } \\
\text { оцінки. }\end{array}$ \\
\hline
\end{tabular}


Завершення табл. 1

\begin{tabular}{|c|c|c|c|c|}
\hline 1 & 2 & 3 & 4 & 5 \\
\hline 3 & \begin{tabular}{l}
\multicolumn{1}{c}{ Індекс } \\
економічної \\
свободи \\
(Index of \\
Economic \\
Freedom, IEF)
\end{tabular} & \begin{tabular}{l}
\multicolumn{1}{c}{ The } \\
Heritage \\
Foundation, \\
The Wall \\
Street \\
Journal
\end{tabular} & $\begin{array}{l}\text { Дослідження } \\
\text { економічних про- } \\
\text { цесів щодо відсут- } \\
\text { ності урядового } \\
\text { втручання або пе- } \\
\text { решкоджання ви- } \\
\text { робництву, розпо- } \\
\text { ділу і споживання } \\
\text { товарів і послуг, за } \\
\text { винятком не обхід- } \\
\text { ної громадянам } \\
\text { захисту і підтримки } \\
\text { свободи }\end{array}$ & $\begin{array}{l}12 \text { показників у } 4 \text { групах: верхо- } \\
\text { венство права (захист права власності, } \\
\text { ефективність судової системи та урядова } \\
\text { сумлінність), обмеження уряду (подат- } \\
\text { ковий тягар, витрати держави, фіскаль- } \\
\text { ний стан), ефективність регулювання } \\
\text { (монетарна свобода, свобода підприєм- } \\
\text { ництва та ринку праці) та відкритість } \\
\text { ринків (свобода інвестування та торгівлі, } \\
\text { фінансова свобода). За кожним показ- } \\
\text { ником оцінка в балах - від } 0 \text { до 100. Ін- } \\
\text { декс розраховується за середнім арифме- } \\
\text { тичним. }\end{array}$ \\
\hline 4 & $\begin{array}{l}\quad \text { Всесвітні } \\
\text { індикатори } \\
\text { державного } \\
\text { управління } \\
\text { (The } \\
\text { Worldwide } \\
\text { Governance } \\
\text { Indicators, } \\
\text { WGI) }\end{array}$ & $\begin{array}{l}\text { Світовий } \\
\text { Банк (World } \\
\text { Bank) }\end{array}$ & $\begin{array}{l}\text { Вимірювання } \\
\text { досягнень країн } \\
\text { світу в якості і } \\
\text { ефективності дер- } \\
\text { жавного управлін- } \\
\text { ня }\end{array}$ & $\begin{array}{l}6 \text { ключових індикаторів на основі } \\
\text { більш ніж } 400 \text { показників (статистичних } \\
\text { та експертних оцінок): врахування думки } \\
\text { населення та підзвітність державних ор- } \\
\text { ганів, політична стабільність і відсут- } \\
\text { ність насильства, ефективність роботи } \\
\text { уряду, якість законодавства, верховенст- } \\
\text { во закону, стримування корупції. }\end{array}$ \\
\hline 5 & \begin{tabular}{l}
\multicolumn{2}{c}{ Міжнарод- } \\
ний індекс \\
захисту прав \\
власності (The \\
International \\
Property Right \\
Index, IPRI)
\end{tabular} & \begin{tabular}{l}
\multicolumn{2}{c}{ Міжна- } \\
родний \\
Альянс \\
прав влас- \\
ності (The \\
Property \\
Rights \\
Alliance)
\end{tabular} & $\begin{array}{l}\text { Вивчення стану } \\
\text { та ефективності } \\
\text { захисту прав при- } \\
\text { ватної власності } \\
\text { (фізичної та інте- } \\
\text { лектуальної). }\end{array}$ & $\begin{array}{l}\text { Показники міжнародних організацій } \\
\text { об'єднані в три основні категорії: право- } \\
\text { ве і політичне середовище, права на фі- } \\
\text { зичну власність, права на інтелектуальну } \\
\text { власність. Оцінка від } 1 \text { до10. }\end{array}$ \\
\hline 6 & \begin{tabular}{l}
\multicolumn{1}{c}{ Індекс } \\
сприйняття \\
корупції (The \\
Corruption \\
Perceptions \\
Index, CPI)
\end{tabular} & \begin{tabular}{l}
\multicolumn{2}{c}{ Міжна- } \\
родна не- \\
урядова \\
організація \\
Transpa- \\
rency \\
International
\end{tabular} & $\begin{array}{l}\text { Вимірюється за- } \\
\text { гальний ступінь } \\
\text { поширеності кору- } \\
\text { пції (частотність і / } \\
\text { або обсяг хабарів) } \\
\text { в державному i } \\
\text { економічному сек- } \\
\text { торах. }\end{array}$ & $\begin{array}{l}\text { Експертні оцінки за результатами } \\
\text { глобального опитування підприємців, } \\
\text { аналітиків по оцінці комерційних ризи- } \\
\text { ків, а також фахівців з різних міжнарод- } \\
\text { них організацій. Індекс ранжирує країни } \\
\text { i території за шкалою від } 0 \text { (найвищий } \\
\text { рівень корупції) до } 100 \text { (найнижчий рі- } \\
\text { вень корупції). }\end{array}$ \\
\hline 7 & \begin{tabular}{l}
\multicolumn{1}{c}{ Індекс } \\
стійкості сус- \\
пільства \\
(Sustainable \\
Society Index, \\
SSI)
\end{tabular} & \begin{tabular}{l}
\multicolumn{1}{c}{ Фонд } \\
сталого \\
суспільства \\
(Sustainable \\
Society \\
Foundation)
\end{tabular} & $\begin{array}{l}\text { Вимірювання } \\
\text { досягнень країн } \\
\text { світу } 3 \text { точки зору } \\
\text { стійкості суспіль- } \\
\text { ного розвитку. }\end{array}$ & $\begin{array}{l}\text { Індекс вимірює досягнення країни за } \\
\text { шкалою від } 0 \text { (найменший ступінь стій- } \\
\text { кості) до } 10 \text { (найвищий ступінь стійкості) } \\
\text { на основі } 24 \text { показників в трьох базових } \\
\text { категоріях: економічний, соціальний та } \\
\text { екологічний розвиток. }\end{array}$ \\
\hline
\end{tabular}

Джерело: систематизовано та складено авторами

Зазначений підхід дозволяє отримати більш достовірну оцінку, в порівнянні 3 моніторингом лише основних соціально-економічних показників, оскільки експертні методи під час оцінювання бізнес-середовища дають 
можливість враховувати показники, за якими можна більшою мірою робити якісні висновки, а також отримувати інтегральну оцінку різнорозмірних показників (через обгрунтування коефіцієнтів вагомості окремих часткових функціональних складників), які використовуються при інтегральному оцінюванні.

Найважливіший рейтинговий показник міжнародних порівнянь, який спрямований на дослідження умов та легкості ведення бізнесу в країні це Index of Doing business - IDB, який насамперед характеризує регуляцію бізнесу державою, зокрема простоту організації й ведення підприємницької діяльності в країні. Динаміка позиції України в рейтингу легкості ведення бізнесу представлена на рис. 1.

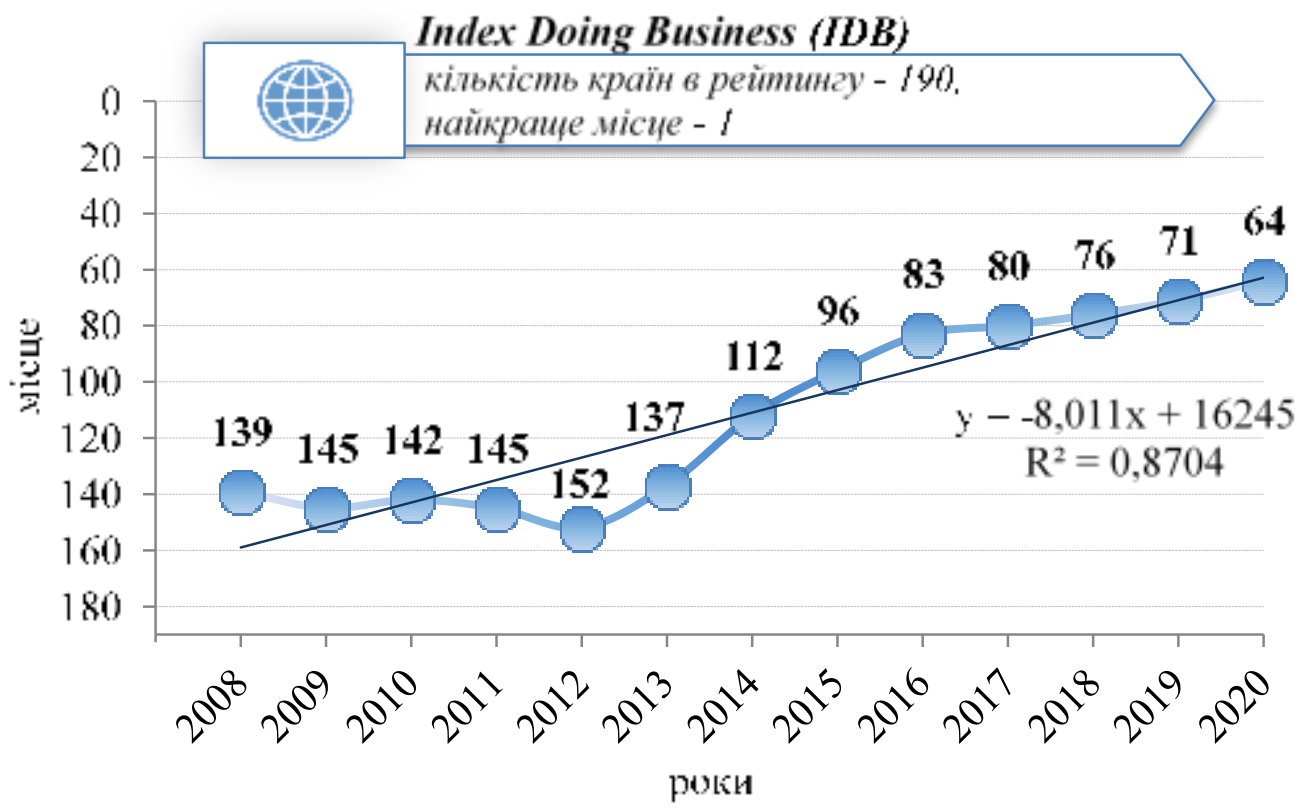

- - Місце України в рейтингу DB — Лінія тренду DB для України

Рис. 1. Динаміка місця України в рейтингу легкості ведення бізнесу (Index Doing Business, IDB) протягом 2008-2020 pp.

Джерело: побудовано за результатами дослідження Світового Банку [8] та власними розрахунками

За результатами дослідженням Світового Банку за підсумками 2019 року Україна в рейтингу легкості ведення бізнесу покращила свою позицію на 7 пунктів і посіла 64 місце серед 190 країн світу. Позитивна динаміка 5 із 10 індикаторів індексу легкості ведення бізнесу забезпечила його зростання з 69,1 до 70,2 балів з максимально можливих 100 балів. Разом із цим проведений регресійний аналіз засвідчив стійку тенденцію до покращення бізнес-середовища в Україні.

За підсумками 2019 року серед регуляторних чинників бізнессередовища України, які за рейтингом IDB Світового Банку справляли найвагоміший вплив на підвищення показника, слід виділити легкість отримання дозволів на будівництво 20 місце серед 190 країн $(81,1$ бала із 100 можливих), доступність кредитів - 
37 місце (75 балів із 100 можливих) та захищеність прав інвесторів - 45 місце (68 балів із 100 можливих). В той же час найсуттєвіші загрози бізнесу пов'язані з вирішенням питань неплатоспроможності позичальника - 146 місце серед 190 країн (лише 31,4 бала iз 100 можливих), а також складностями $з$ підключенням до електромереж - 128 місце у рейтингу Doing Business.

Поліпшення бізнес-середовища України досягнуто, головним чином, за рахунок підвищення рівня захисту прав інвесторів шляхом відкриття інформації про кінцевих бенефіціарів та спрощення процедури отримання дозволу на будівництво завдяки усуненню вимог щодо найму незалежного проектанта й інженера технагляду, введення системи онлайн-повідомлень та зменшення вартості дозволів на будівництво в межах Києва.

Спрощення процедури підключення до електромереж, реєстрації власності та сприяння міжнародній торгівлі завдяки зменшенню вимог до сертифікації окремих промислових товарів в сукупності справили стимулюючий вплив на легкість ведення бізнесу в Україні та компенсували негативну динаміку за показниками легкості сплати податків, реєстрації бізнесу, вирішення проблем неплатоспроможності підприємств, доступу до кредитів та забезпечення виконання контрактів.

В результаті країнами, що мають подібне з Україною бізнес середовище у 2020 році (знаходяться в тому ж квартилі за рейтингом Doing Business), $\epsilon$ Італія, Мексика, Болгарія, Саудівська Аравія, Індія, Колумбія, Узбекистан,
В'єтнам, Ямайка, Греція. Динаміка показників бізнес-середовища України у 2019 році в розрізі стимуляторів та дестимуляторів суб'єктів підприємництва представлена на рис. 2.

Слід відмітити якість проведених реформ у Грузії, що дозволило піднятися цій країні у рейтингу на 7 місце серед 190 країн, а незмінними лідерами протягом останніх 5 років залишаються Нова Зеландія та Сінгапур.

Рейтинг Doing Business $є$ ключовим при оцінці бізнес-середовища, оскільки передбачає вимірювання регуляторних норм та рівня бюрократії, що супроводжують підприємницьку діяльність. Тому доцільним $є$ аналіз інших рейтингових систем для комплексного оцінювання якісних ендогенних характеристик бізнес-середовища.

Найбільш авторитетним із міжнародних рейтингів оцінки чинників конкурентного середовища в різних країнах $є$ Рейтинг глобальної конкурентоспроможності (Global Competitiveness Index (GCI), що включає низку макроекономічних показників, у тому числі показники розвитку фінансового ринку, ринку праці, ринку товарів та послуг, рівня технологічного розвитку, інноваційного потенціалу, системи охорони здоров'я, освіти. Розраховується щорічно для більш ніж 139 країн світу. В результаті кожна країна має детальний опис 3 визначенням загальної позиції в рейтингу та за окремими конкурентними перевагами та недоліками. Україна за рейтингом глобальної конкурентоспроможності у 2019 році посіла 85 позицію серед 141 країни, що на 2 позиції нижче, ніж у попередньому 2018 році (рис. 3). 


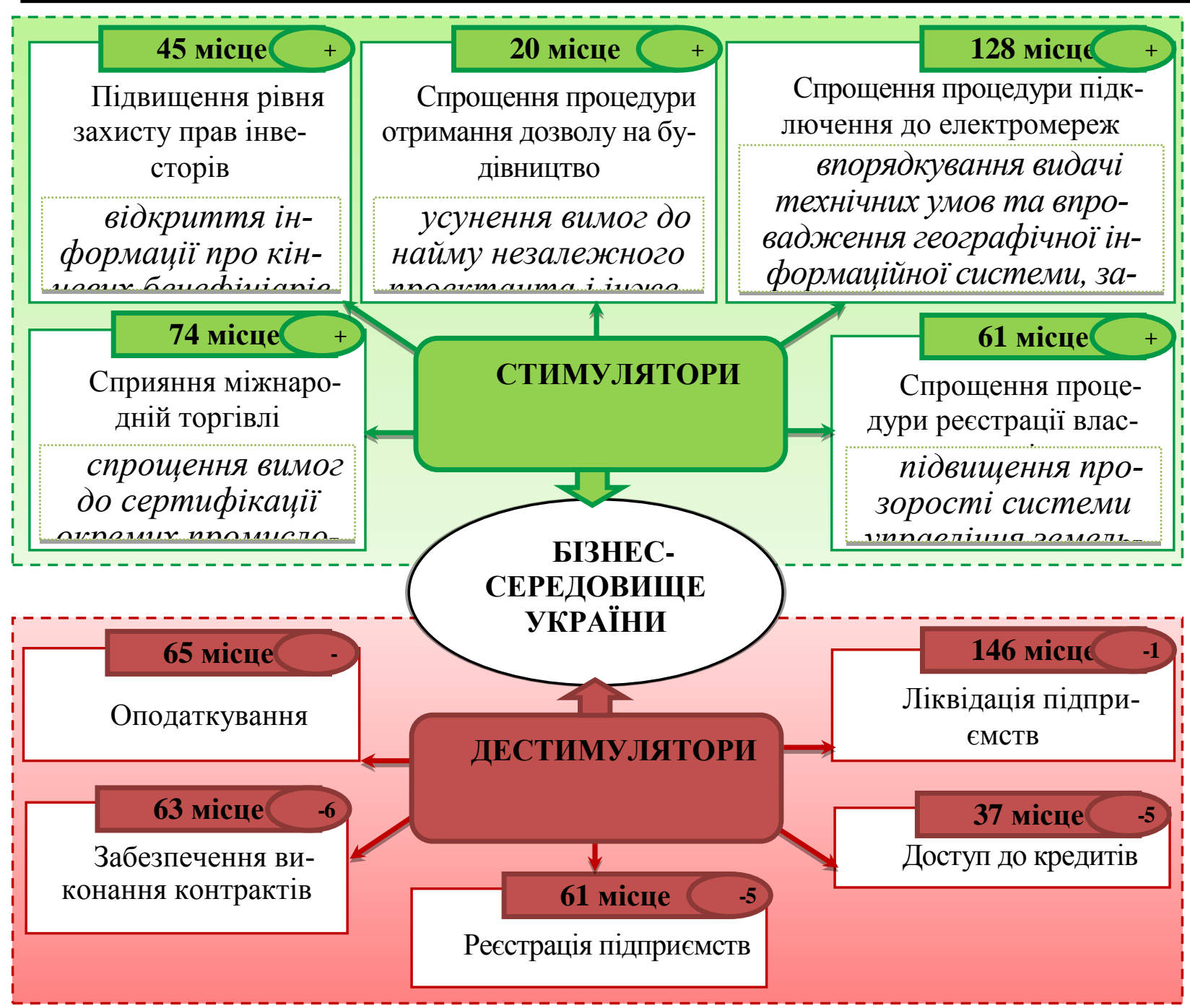

Рис. 2. Аналіз чинників бізнес-середовища України у 2020 році Джерело: побудовано за рейтингом легкості ведення бізнесу Світового Банку [8]

При цьому проведений регресійний аналіз засвідчив незначну тенденцію до покращення бізнес-середовища в Україні, зокрема, порівняно 3 докризовим 2007 роком, на відміну від суттєвого покращення показників за рейтингом Doing Business, що пояснюється врахуванням значно ширшого переліку різнопланових показників у рейтингу GCI та, відповідно, існуванням загроз бізнесу в макроекономічній cфepi.

За результатами аналізу динаміки індикаторів Індексу глобальної конкурентоспроможності виявлено реальні (критичні відставання) та потенційні загрози бізнес-середовища України, пов'язаних із занадто низьким рівнем розвитку фінансового ринку й фінансовою нестабільністю в країні (136 позиція із 141 країни, гірші показники мають лише Венесуела, Мавританія, Ангола, Чад та Смен), макроекономічною нестабільністю (133 позиція), неефективністю державного управління (104 позиція) та незадовільним станом системи охорони здоров'я (101 позиція), що в умовах пандемії COVID-19 $\epsilon$ джерелом принципово нових, максимально небезпечних загроз. 


\section{Wlobal Competitiveness Index (GCI) \\ Forum naйkpaue wicue - I}

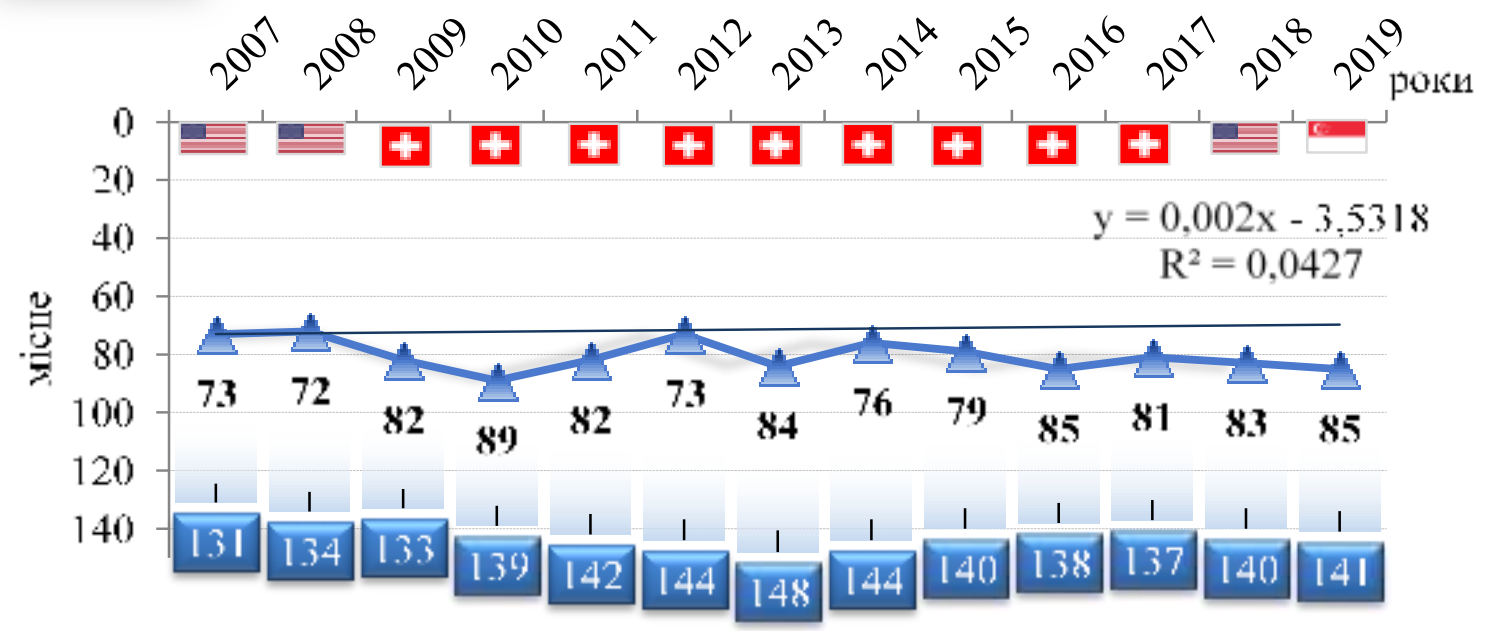

Кількість країн в рейтингу

$\triangle$ Місце України в рейтингу GСI

— Лінія тренду GCl України

Рис. 3. Динаміка місця України в рейтингу глобальної конкурентоспроможності (GCI) протягом 2007-2019 pp.

Джерело: побудовано за даними World Economic Forum [9]

В рейтингу економічної свободи найкращим показником за період 3 Україна за підсумками 2019 року під- 2008 року. нялася на 13 позицій й посіла 134 місце серед 180 країн (рис. 4), що стало

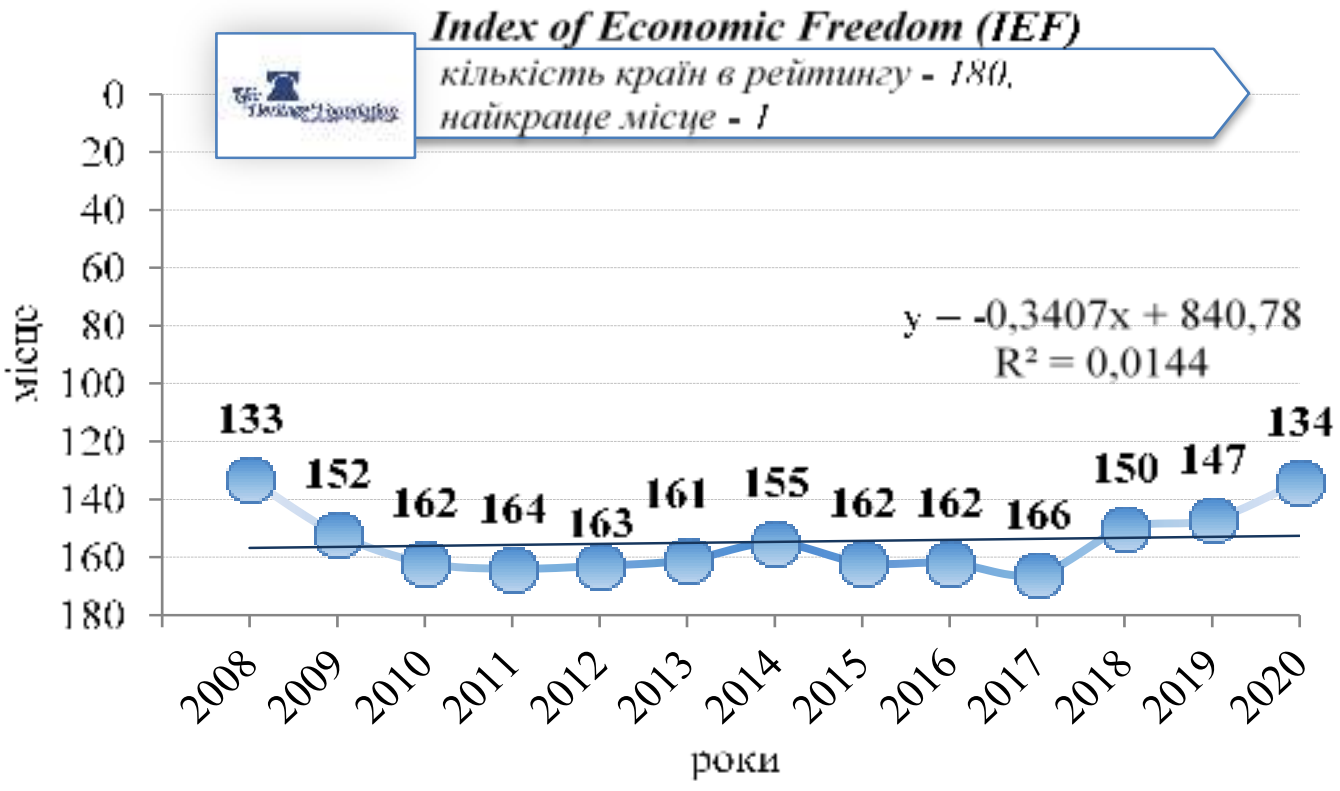

Місце України в рейтингу IEF — Лінія тренду IEI для України

Рис. 4. Динаміка місця України в рейтингу економічної свободи протягом 20082020 pp. (Index of Economic Freedom, IEF)

Джерело: побудовано за результатами дослідження Heritage Foundation [10] 
Проте Індекс економічної свободи України становить лише 54,9 балів, що за типологізацією Heritage Foundation відповідає «переважно невільній економіці» (mostly unfree), а до 2018 року Україна взагалі належала до категорії «деспотичних» (repressed) країн 3 показником, що не перевищував 50 балів із 100 можливих. Позитивна динаміка позицій України за IEF в 2019 році стала наслідком підвищення показників 8 із 12 субіндексів, особливо - субіндексів ефективність судочинства (з 31,5 до 42,2), доброчесність уряду (з 29,6 до 37,9 ) та свобода торгівлі $(3$ 75,0 до 81,2). Проте за оцінками експертів Heritage Foundation нормативно-правова база України теоретично забезпечує майнові інтереси бізнесу, але захист майнових прав судовою гілкою влади залишається на низькому рівні через політичний тиск на неї та корупцію.
Згідно $з$ результатами дослідження індикаторів державного управління Worldwide Governance Indicators (WGI) Світового Банку якість і ефективність державного управління в Україні перебуває на вкрай низькому рівні, оскільки значення всіх шести контрольних індикаторів не перевищують 50 балів із 100 можливих (табл. 2.), а за показниками політичної стабільності та відсутності насильства Україна в 2019 році отримала лише 8,57 балів зі 100, перебуваючи на рівні 3 африканськими країнами та країнами 3 постійними військовими конфліктами (Венесуела, Нікарагуа, Туреччина, Афганістан, Ірак, Іран, Пакистан, Сомалі та ін.), що свідчить про інституційні деформації та системні загрози розвитку бізнесу.

Таблиця 2

Позиції України за Всесвітніми індикаторами державного управління

\begin{tabular}{|c|c|c|c|c|c|c|c|c|c|}
\hline $\begin{array}{r}N \\
3 / \Pi \\
\end{array}$ & 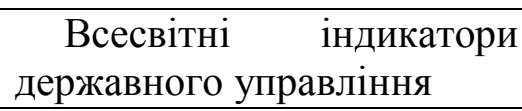 & $\begin{array}{l}201 \\
2 \mathrm{p} .\end{array}$ & $\begin{array}{l}201 \\
3 \mathrm{p} . \\
\end{array}$ & $\begin{array}{l}201 \\
4 \mathrm{p} .\end{array}$ & $\begin{array}{l}201 \\
5 \mathrm{p} .\end{array}$ & $\begin{array}{l}201 \\
6 \mathrm{p}\end{array}$ & $\begin{array}{c}201 \\
7 \mathrm{p} .\end{array}$ & $\begin{array}{l}201 \\
8 \mathrm{p} .\end{array}$ & $\begin{array}{l}201 \\
9 \mathrm{p} .\end{array}$ \\
\hline & $\begin{array}{l}\text { Врахування думки насе- } \\
\text { лення та підзвітність дер- } \\
\text { жавних органів }\end{array}$ & $\begin{array}{l}40,3 \\
8\end{array}$ & $\begin{array}{l}37,5 \\
6\end{array}$ & $\begin{array}{l}43,3 \\
5\end{array}$ & $\begin{array}{l}43,8 \\
4\end{array}$ & $\begin{array}{l}47,7 \\
8\end{array}$ & $\begin{array}{l}47,7 \\
8\end{array}$ & $\begin{array}{l}44,8 \\
3\end{array}$ & $\begin{array}{l}48,2 \\
8\end{array}$ \\
\hline & $\begin{array}{l}\text { Політична стабільність i } \\
\text { відсутність насильства }\end{array}$ & $\begin{array}{l}41,7 \\
1\end{array}$ & $\begin{array}{l}20,8 \\
5\end{array}$ & 5,71 & 5,24 & 6,67 & 6,67 & 5,71 & 8,57 \\
\hline & $\begin{array}{l}\text { Ефективність роботи } \\
\text { уряду }\end{array}$ & $\begin{array}{l}32,2 \\
3\end{array}$ & $\begin{array}{l}31,2 \\
8\end{array}$ & $\begin{array}{l}39,9 \\
0\end{array}$ & $\begin{array}{l}34,6 \\
2\end{array}$ & $\begin{array}{l}32,2 \\
1\end{array}$ & $\begin{array}{l}35,1 \\
0\end{array}$ & $\begin{array}{l}38,4 \\
6\end{array}$ & $\begin{array}{l}39,9 \\
0\end{array}$ \\
\hline & Якість законодавства & $\begin{array}{l}29,8 \\
6\end{array}$ & $\begin{array}{l}30,3 \\
3\end{array}$ & $\begin{array}{l}29,3 \\
3\end{array}$ & $\begin{array}{l}29,8 \\
1\end{array}$ & $\begin{array}{l}39,0 \\
6\end{array}$ & $\begin{array}{l}40,3 \\
8\end{array}$ & $\begin{array}{l}40,8 \\
7\end{array}$ & $\begin{array}{l}42,3 \\
1\end{array}$ \\
\hline & Верховенство закону & $\begin{array}{l}26,2 \\
9\end{array}$ & $\begin{array}{l}23,9 \\
4\end{array}$ & $\begin{array}{l}23,0 \\
8\end{array}$ & $\begin{array}{l}22,1 \\
2\end{array}$ & $\begin{array}{l}24,5 \\
2\end{array}$ & $\begin{array}{l}25,0 \\
0\end{array}$ & $\begin{array}{l}24,0 \\
4\end{array}$ & $\begin{array}{l}25,4 \\
8\end{array}$ \\
\hline & Стримування корупції & $\begin{array}{l}12,8 \\
0\end{array}$ & $\begin{array}{l}11,3 \\
7\end{array}$ & $\begin{array}{l}14,9 \\
0\end{array}$ & $\begin{array}{l}14,9 \\
0\end{array}$ & $\begin{array}{l}21,1 \\
5\end{array}$ & $\begin{array}{l}22,1 \\
2\end{array}$ & $\begin{array}{l}18,2 \\
7\end{array}$ & $\begin{array}{l}26,4 \\
4\end{array}$ \\
\hline
\end{tabular}

Джерело: складено за рейтингом WGI Світового Банку [11]

Аналізуючи динаміку та фактичні значення індикаторів державного управління Світового Банку можна дійти до висновку, що в бізнес- середовищі України сформувалися такі системні загрози суб'єктам підприємництва: 
1) політична нестабільність та вій- Index (IPRI) України в 2019 році зросськова агресія на сході країни; ла на 0,149 до 4,432 3 можливих

2) недосконалість законодавства в сфері регулювання бізнесу;

3) неефективність роботи правоохоронних органів та судової влади;

4) корупція у всіх сферах бізнесу та влади;

5) неефективна державна політика щодо розвитку бізнесу;

6) недотримання конституційних прав та свобод.

Оцінка індексу захисту прав власності - The International Property Right 10 балів, посівши 109 місце у світі зі 129 досліджуваних країн та одне 3 останніх місць у Європі.

Найскладніша ситуація в Україні за показниками правового та політичного середовища, так оцінка юридичного та політичного субіндексу IPRI в Україні зросла на 0,286 до 2,971 з оцінками 1,968 за політичну стабільність, 2,906 за незалежність судової влади, 3,432 за контроль над корупцією та 3,577 за верховенство права (рис. 5).

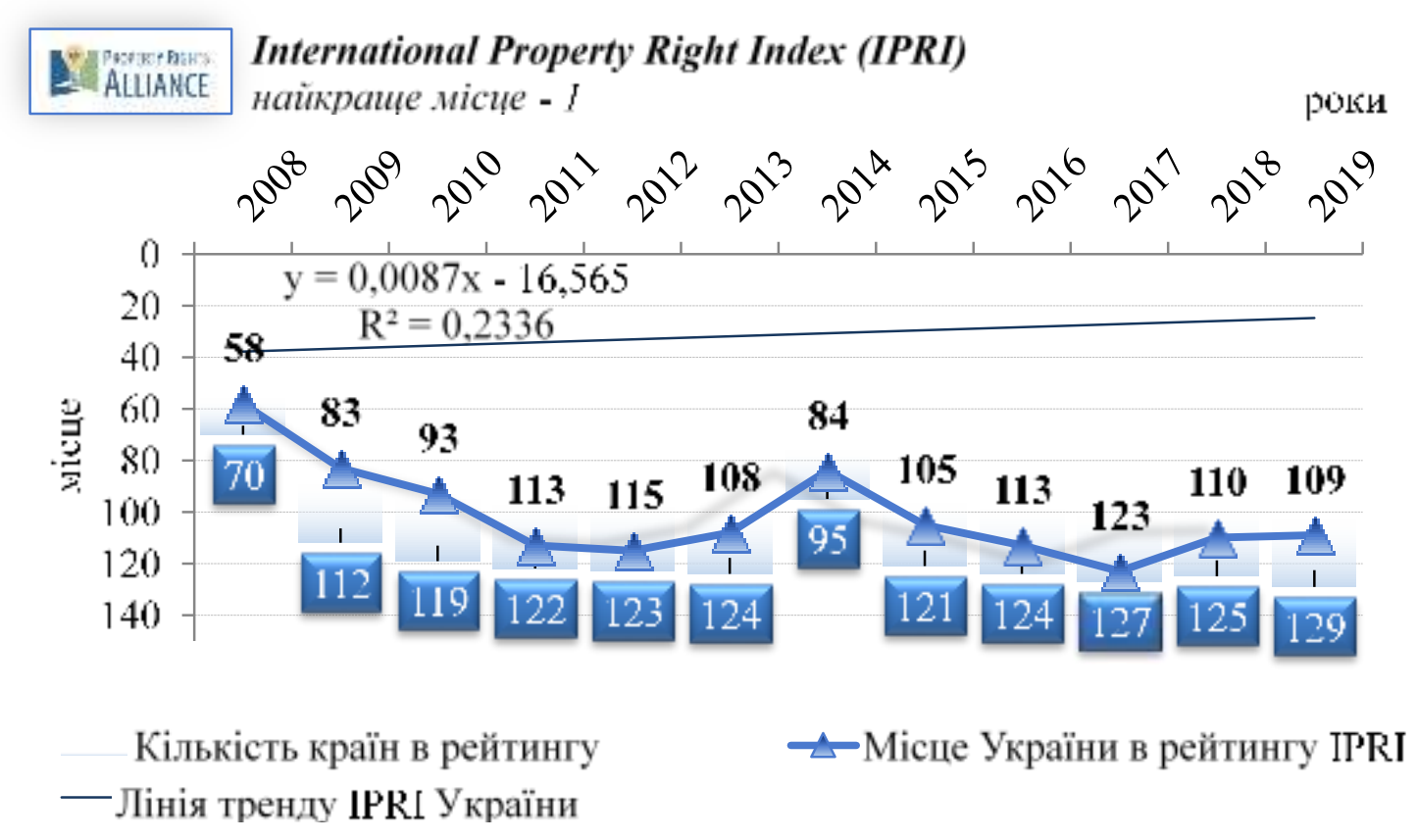

Рис. 5. Динаміка місця України в рейтингу захисту прав власності протягом 2008-2019 pp. (The International Property Right Index, IPRI) Джерело: побудовано за даними [12]

Як видно з рис. 6 субіндекс прав на фізичне майно в Україні збільшився на 0,021 до 5,747 з 10 можливих 3 найвищою оцінкою за показником реєстрації власності 9,406 та оцінками 3,867 у оцінці захисту прав власності й 3,968 у спрощенні доступу до позик.
Оцінка субіндексу в галузі прав інтелектуальної власності в Україні зросла на 0,142 до 4,578 з 10 можливих та оцінками 3,986 за «Сприйняття захисту інтелектуальної власності», 7,75 за захист патентів та 2 за захист авторських прав. 


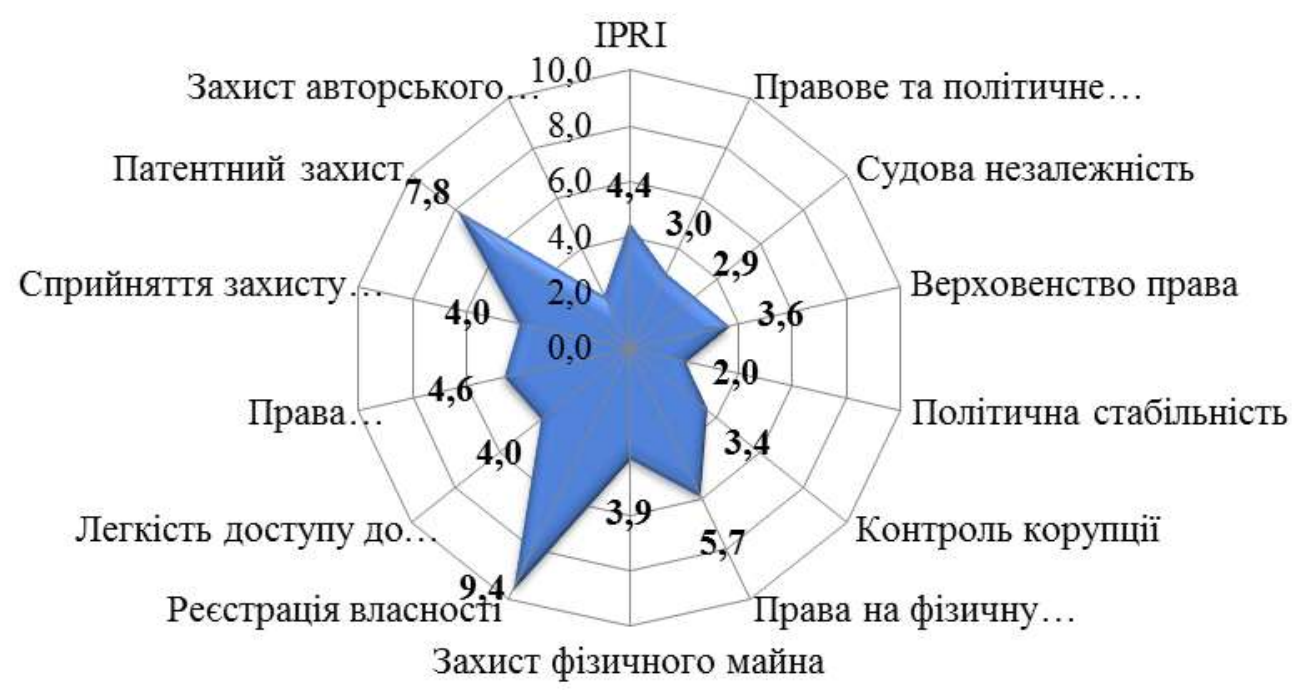

Рис. 6. Структура індексу захисту прав власності (IPRI) України в 2019 p.

Джерело: побудовано за даними [10]

Висновки. Своєчасне й неупереджене оцінювання стану бізнессередовища має важливе значення для формування та реалізації соціальноекономічної політики держави. Використання аналітичного інструментарію транснаціональних компаративних індексних систем спрямовано на виявлення сучасних проблем розвитку бізнесу в Україні. Проблемами, на подолання яких мають бути спрямовані заходи зі сприяння розвитку бізнесу, в Україні $є$ : критично низький показник рівня сприятливості економічного та правового середовища щодо ведення підприємницької діяльності, зокрема у рейтингах країн, які складаються провідними міжнародними економічними організаціями; низьке значення показника інтегральної оцінки більшості функціональних складових економічної безпеки суб'єктів підприємництва та незадовільні темпи їх покращення; погіршення значень макроекономічної, зовнішньоекономічної, інвестиційної, інноваційної функціональних складових; незадовільні показники фінансового стану та ефективності функціонування підприємств, використання ними ресурсного забезпечення; негативні тенденції щодо кількості діючих, новостворюваних та обсягів господарської діяльності підприємств; збільшення кількості кримінальних посягань, корупційних та дискримінаційних дій на підприємців; низький рівень конкурентоспроможності підприємств та їх інноваційної активності тощо.

\section{Список використаної літератури}

1. Хроніки бізнес-кризи: кого в Україні найбільше охопить шторм коронавіpycy. Економічна правда. URL: https://www.epravda.com.ua/rus/publications/ 2020/03/19/658296/. (дата звернення 28.08.2020). 
2. Котлер Ф., Касліоне Дж.А. Хаотика: управління та маркетинг в епоху турбулентності (Хаотика: управління та маркетинг в епоху турбулентності). К: Ciмджест, ПЛАСКЕ, 2009. 208 с.

3. Мельник М. I. Формування бізнес-середовища України в умовах інституційних трансформацій: монографія. Львів: ІРД НАН України, 2012. 568 с.

4. Біла І.С., Насікан Н.І. Бізнес-середовище в Україні. Глобальні та нащуіональні економічні проблеми, 2017. Вип. 17. С. 127-131

5. Портер М. Е. Конкурентная стратегия: Методика анализа отраслей и конкурентов. М.: Альпина Бизнес Букс, 2005. 454 с.

6. Конкурентні стратегії безпеки розвитку України у глобальному середовищі / за. ред.: А. І. Мокій. Львів, 2019. 872 с.

7. Варналій 3.С., Васильців Т.Г., Білик Р.Р. Забезпечення конкурентоспроможності та економічної безпеки малого і середнього підприємництва України. Вісник Академї праџі і соціальних відносин Федераџії профспілок України, 2015. № 3-4. C. 44-50.

8. Index of Doing business. The World Bank. URL:https://doingbusiness.org/ (дата звернення 28.08.2020)

9. Global Competitiveness Index (GCI). The World Economic Forum. URL: https://www.weforum.org/ (дата звернення 28.08.2020).

10. Index of Economic Freedom (IEF). Wall Street Journal. URL: http://www.heritage.org/index/ (дата звернення 28.08.2020).

11. Worldwide Governance Indicators. The World Bank. URL: https://info.worldbank.org/governance/wgi/Home/Reports (дата звернення 28.08.2020).

12. International Property Right Index. The Property Rights Alliance. URL: https://internationalpropertyrightsindex.org/ (дата звернення 28.08.2020).

13. Маслій О.А. Вплив системних загроз економічній безпеці України на конкурентоспроможність національної економіки. Науковий вісник Міжнародного гуманітарного університету. Серія: «Економіка і менеджмент», 2019. №36. С. $58-64$.

14. Onyshchenko S., Maslii O., Ivanyuk B. The impact of the external environment on the economic security of Ukrainian business. Economics and Region, 2020. №1 (76).P. 22-29. 